\title{
Prehodna levkemija (prehodna motnja mielopoeze) pri novorojenčku z Downovim sindromom
}

\section{Clinical case: Transient leukaemia (transient abnormal myelopoiesis) in a newborn with Down syndrome}

Vita Čas, Aneta Soltirovska Šalamon, Marko Kavčič

\section{Izvleček}

V prispevku opisujemo primer novorojenčka z Downovim sindromom (DS), pri katerem se je dan po rojstvu razvila dihalna stiska. Prisotna je bila levkocitoza s povišanim deležem blastov (22\%), nato pa so se pojavili tudi hepatosplenomegalija, znaki hiperviskoznega sindroma ter infiltrati blastov na koži obraza in nosni sluznici.

Ugotovili smo prehodno motnjo mielopoeze (angl. transient abnormal myelopoiesis, TAM) oz. prehodno levkemijo (PL-DS), ki se pojavi pri 5-10\% novorojenčkov z DS. PL-DS se značilno pojavi le v kombinaciji trisomije 21 (DS ali mozaicizem) in mutacije gena GATA1 transkripcijskega faktorja.

Pri večini otrok PL-DS poteka brez simptomov, prisotnost blastov v periferni krvi pa spontano izzveni v 2-3 mesecih. Kljub temu do $20 \%$ otrok s PL-DS umre v prvih šestih mesecih življenja. Ob zgodnji uvedbi zdravljenja s citarabinom pri simptomatskih bolnikih preprečujemo zgodnjo umrljivost. Približno $20 \%$ otrok s PL-DS v prvih štirih letih življenja zboli z akutno megakarioblastno levkemijo - mieloidno levkemijo, povezano z Downovim sindromom (ML-DS), pri kateri je v blastih prisotna za bolnika specifična mutacija gena GATA1, poznana že iz obdobja PL-DS. Hipotezo, da bi v primeru eradikacije blastov že v obdobju PL-DS preprečili prehod v ML-DS, so ovrgli.

Pomembno je, da pri novorojenčkih z DS čim prej odkrijemo tiste s PL-DS, s čimer preprečimo zgodnje smrti in čim prej odkrijemo morebitni prehod do ML-DS.

Ključne besede: Downov sindrom, prehodni mieloproliferativni sindrom, transkripcijski faktor GATA1, akutna mieloidna levkemija.

\section{Abstract}

We present the case of a newborn with Down syndrome (DS) in whom respiratory distress with leukocytosis and an increased proportion of blasts (22\%) developed on the day after birth. Later, hepatosplenomegaly, signs of hyperviscosity syndrome and blast infiltrates in the skin of the face and the nasal mucosa appeared.

We diagnosed Transient Abnormal Myelopoiesis (TAM) or so-called transient leukaemia (TL-DS), which occurs in 5-10\% of newborns with DS. TL-DS is characterised by its occurrence only in combination with trisomy 21 (DS or mosaicism) and the GATA1 mutation.

In most cases, TL-DS is asymptomatic and the presence of blasts in the peripheral blood disappear spontaneously within 2-3 months. However, up to $20 \%$ of children with TL-DS die within the first six months of life. With the early use of cytarabine treatment in symptomatic patients, early death can be prevented. About $20 \%$ of children with TL-DS progress to acute megakaryocyte leukaemia within the first fouryears of life - myeloid leukaemia associated with Down syndrome (ML-DS), where the blast contains a patient-specific GATA1 mutation known from the TL-DS period. The hypothesis that blast eradication in the PL-DS period would prevent the transition to ML-DS has been refuted. In neonates with DS, timely detection of children with PL-DS is important to prevent early death and for early detection of possible progression to ML-DS.

Key words: Down syndrome, Transient Myeloproliferative Syndrome, GATA1 transcription factor, Acute Myeloid Leukaemia. 


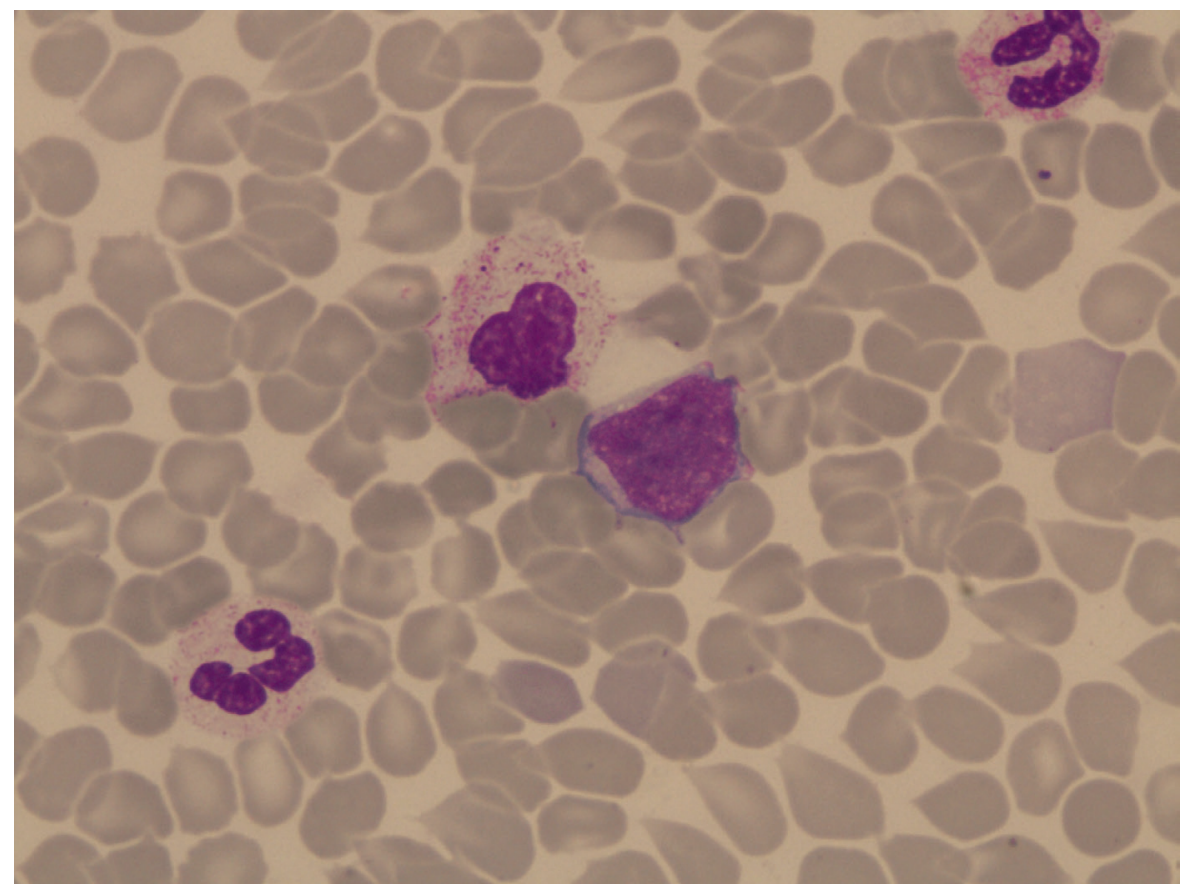

SLIKA 1. KRVNI RAZMAZ PERIFERNE KRVI S PRISOTNIMI BLASTI PRI NAŠEM BOLNIKU S PL-DS.

FIGURE 1. PERIPHERAL BLOOD SMEAR WITH PRESENCE OF BLASTS IN OUR PATIENT WITH TL-DS.

\section{Uvod}

Trisomija 21. kromosoma, ki povzroča Downov sindrom (DS), je najpogostejša kromosomska mutacija s pojavnostjo $1 / 800$ živorojenih otrok (1).

Pri novorojenčkih z DS lahko v prvih tednih življenja opazimo hematološke posebnosti, kot so nevtrofilija, trombocitopenija in policitemija. Te izzvenijo v nekaj tednih, nadomestita pa jih blaga trombocitoza in povečan srednji volumen eritrocitov (angl. mean corpuscular volume, MCV), ki pri dveh tretjinah bolnikov vztraja celo življenje. Anemija in nevtropenija se pri novorojenčkih z DS pojavljata redko in sta največkrat posledici pridruženih stanj (2).

Otroci z DS imajo večje tveganje za razvoj levkemij, solidni tumorji pa se pri njih pojavljajo redkeje. $V$ starosti do pet let je tveganje za razvoj akutne mieloidne levkemije (AML) pri otrocih z DS kar 150-krat večje kot pri vrstnikih brez DS, tveganje za razvoj akutne limfoblastne anemije (ALL) pa 40-krat večje. Med 5. in 30. letom starosti je pri otrocih z DS je pričel spontano $z$ razpokom plodovih ovojev. Rojen je bil po naravni poti s težo $3450 \mathrm{~g}$, dolžino $53 \mathrm{~cm}$ in obsegom glave $33 \mathrm{~cm}$. Ocena po Apgarjevi je bila $7 / 8 / 8$.

Pri prvem pregledu so bili pri dečku vidni dismorfni znaki, značilni za Downov sindrom (brazda štirih prstov, nizko položena ušesa, navzdol potekajoči očesni reži, hipertelorizem, večji jezik, sploščen obraz, izrazita centralna hipotonija).

Prvi dan po porodu se je pri dečku razvila dihalna stiska. Za vzdrževanje primerne saturacije je potreboval do $3 \mathrm{l} / \mathrm{min}$ dodatka kisika. V laboratorijskih izvidih so poleg hipoglikemije $(1,7 \mathrm{mmol} / \mathrm{l})$ izstopale povišane vrednosti vnetnih parametrov (CRP $22 \mathrm{mg} / \mathrm{l})$, levkocitoza $\left(60 \times 10^{9} / \mathrm{l}\right)$ in trombocitopenija $\left(76 \times 10^{9} / \mathrm{l}\right)$. V diferencialni sliki periferne krvi je bil prisoten povečan delež blastov ( $22 \%)$. Po odvzemu kužnin je bilo zaradi suma na zgodnjo neonatalno sepso uvedeno antibiotično zdravljenje $z$ ampicilinom in gentamicinom.

Še isti dan je bil zaradi suma na Downov sindrom ter zaradi lvkocitoze in dihalne stiske premeščen na Klinični oddelek za neonatologijo Pediatrične klinike.

Ob sprejemu je bil ob dodatku kisika evpnoičen s primerno vrednostjo saturacije. Otipali smo blago povečana jetra in vranico. Kisik je potreboval le do starosti 24 ur.

V laboratorijskih izvidih ob sprejemu so bili prisotni izrazita levkocitoza (63 $\left.x 10^{9} / l\right)$ in znaki hiperproliferacije levkocitov (povišana vrednost LDH, mejna vrednost urata), $v$ razmazu periferne krvi pa so bili vidni številni blasti (58\%) (Slika 1). Jetrna funkcija je bila vseskozi ustrezna, znakov diseminirane intravaskularne koagulacije (DIK) ni imel.

Z ultrazvočno preiskavo (UZ) trebuha smo videli blago splenomegalijo. Rentgensko slikanje prsnih organov (RTG pc) je pokazalo poudarjen intersticijski vzorec, medtem ko plevralnega ali perikardialnega izliva ni imel. Na UZ srca 
je bil viden defekt septuma preddvorov velikosti 4-5 mm z levo-desnim šantom in brez perikardialnega izliva.

$S$ citogenetsko analizo celic smo potrdili Downov sindrom s klasičnim kariotipom 47, XY, +21. V sklopu osnovnega stanja je bila pri dečku ugotovljena tudi prirojena katarakta obojestransko.

Izvidi opravljenih preiskav periferne krvi (morfologija, pretočna citometrija, citogenetika) so pokazali, da gre za akutno mieloblastno levkemijo (akutno megakarioblastno obliko M7 po FAB). Imunofenotip levkemičnih celic (CD34+, CD13-) je govoril v prid PL-DS (megakarioblastna levkemija izraža tudi CD13).

Naknadno smo z metodo sekvenciranja naslednje generacije (angl. next-generation sequencing, NGS) odkrili dve pomembni mutaciji v genu za transkripcijski faktor GATA1, ki sta pri PL-DS povezani s kasnejšo pojavnostjo ML-DS.

Med bolnišničnim zdravljenjem sta se razvila vezikulopustularen izpuščaj na koži obraza in lasišča ter slaba prehodnost nosu kot posledica verjetnega levkemičnega infiltrata v nazofarinksu (Slika 2). Deček je imel klinične znake hiperviskoznega sindroma (motnje čuječnosti, motnje hranjenja, težave z dihanjem s prehodno hiperkapnijo).

Glede na klinični potek, vztrajanje levkocitoze, kliničnih težav z dihanjem in pretirane zaspanosti smo se odločili za zdravljenje s kemoterapijo po protokolu AML BFM 2019 (AML Berlin-Frankfurt -Münster 2019) s citarabinom v odmerku $1,5 \mathrm{mg} / \mathrm{kg}$ telesne teže $v 5$ minutah iv., enkrat na dan, 7 dni zapored.

Ob zdravljenju je prišlo do kliničnega izboljšanja (težave z dihanjem so izzvenele, koža se je zacelila, otrok je bil bolj živahen) in zmanjšanja števila levkocitov. Zaradi zavore kostnega mozga po zdravljenju s kemoterapevtikom je deček trikrat potreboval transfuzijsko zdravljenje s trombociti, anemija in nevtropenija pa sta se spontano popravili. Drugih neželenih učinkov ni razvil.

Dečka smo redno sledili v hematoonkološki ambulanti.
V starosti 12 tednov smo iz vzorca periferne krvi izmerili minimalno preostalo bolezen (angl. minimal residual disease, MRD), ki je pokazala prisotnost $\mathbf{0 , 0 3} \%$ levkemičnih celic $z$ enakim imunofenotipom (CD7+/CD34+/CD36+/ CD45+) kot ob postavitvi diagnoze.

V starosti 6 mesecev je bilo v periferni krvi prisotnih 1,5 \% levkemičnih celic, v kostnem mozgu dva tedna kasneje pa 5,3\%. V hemogramu sta bili prisotni nevtropenija (AŠN $990 \times 10^{9} / \mathrm{l}$ ) in trombocitopenija (116 x 109/l). V starosti 11 mesecev smo zaradi poglabljajoče se trombocitopenije $\left(<20 \times 10^{9} /\right.$ l) opravili aspiracijsko biopsijo kostnega mozga in ugotovili, da so blasti zajemali že več kot tretjino vseh enojedrnih celic. Deček je s tem izpolnjeval merila za postavitev diagnoze akutna megakarioblastna levkemija (FAB klasifikacija AML-M7) brez infiltratov v osrednjem živčnem sistemu. Uvedli smo zdravljenje z visokodozno kemoterapijo po protokolu AML BFM 2019 ML-DS.

\section{Razpravljanje}

\section{Definicija PL-DS}

PL-DS večinoma prepoznamo v prvih osmih tednih življenja, povprečno v 3.-7. dnevu življenja (9).

Diagnozo PL-DS postavimo pri novorojenčku/dojenčku s trisomijo 21 (Downovim sindromom ali mozaicizmom) s povečanim deležem blastov (> $5 \%$ ) v periferni krvi ali znaki PL-DS ter dokazano mutacijo gena GATA1 (Tabela 1) $(4,10)$.

V našem primeru smo na oddelek sprejeli novorojenčka s klinično sliko, sumljivo za Downov sindrom, ki smo ga kasneje tudi citogenetsko potrdili. V periferni krvni sliki je bil povečan delež blastov (58\%). Glede na klinične znake in laboratorijske izvide smo postavili sum na PL-DS, ki smo jo kasneje tudi potrdili z dokazom mutacije v genu GATA1.

\section{Patofiziologija PL-DS}

Pri PL-DS gre za prehodno klonalno proliferacijo mieloidnih blastov z megakarioblastnimi in eritroblastnimi značilnostmi, ki se prične že prenatalno v plodovih jetrih in se pojavlja izključno pri otrocih s trisomijo 21 (DS ali mosaicizmom) (11-13).

Je posledica kombinacije trisomije $\mathbf{2 1}$, ki je odgovorna za povečano proliferacijo megakarioblastnih-eritroblastnih celic, ter somatske mutacije v X-vezanem genu GATA1, ki povzroči skrajšanje beljakovine hematopoetskega transkripcijskega faktorja GATA1, ki je odgovoren za dozorevanje megakarioblastov in eritroblastov. Novonastala krajša beljakovina GATA1s vpliva na slabše dozorevanje in hitrejšo proliferacijo megakarioblastov, s čimer se prične neoplastični proces blastov v plodovih jetrih $(12,13)$.

\section{Klinična slika PL-DS}

Večina otrok s PL-DS (66-84\%) je brezsimptomnih in doseže spontano remisijo povečanega deleža blastov v 2-3 mesecih.

Pri simptomatskih bolnikih je klinična slika raznovrstna. Tudi pri njih lahko pride do spontane remisije, približno 20 \% bolnikov pa ogroža t. i. zgodnja smrt v prvih 6 mesecih življenja, ki je najpogosteje posledica infiltracije jeter z blasti, fibroze jeter in posledične jetrne odpovedi $(8,13,14)$.

Pri 10-15 \% novorojenčkov z DS, ki nimajo povečanega deleža blastov $v$ periferni krvi (<5\%) ali kliničnih znakov bolezni, imajo pa dokazano mutacijo gena GATA1, govorimo o »tihi PL-DS« (4).

Redko (<5\%) PL-DS ugotovimo že pri plodu z DS. Z UZ preiskavo v 2. ali 3. trimesečju lahko vidimo hepatomegalijo ali splenomegalijo in hidrops ploda $z$ ascitesom in perikardialnim ali plevralnim izlivom. Napoved izida PL-DS pri plodu je slaba (skupno $>60$ $\%$ intrauterina in perinatalna umrljivost), a obstajajo tudi poročila o spontani remisiji (14). 


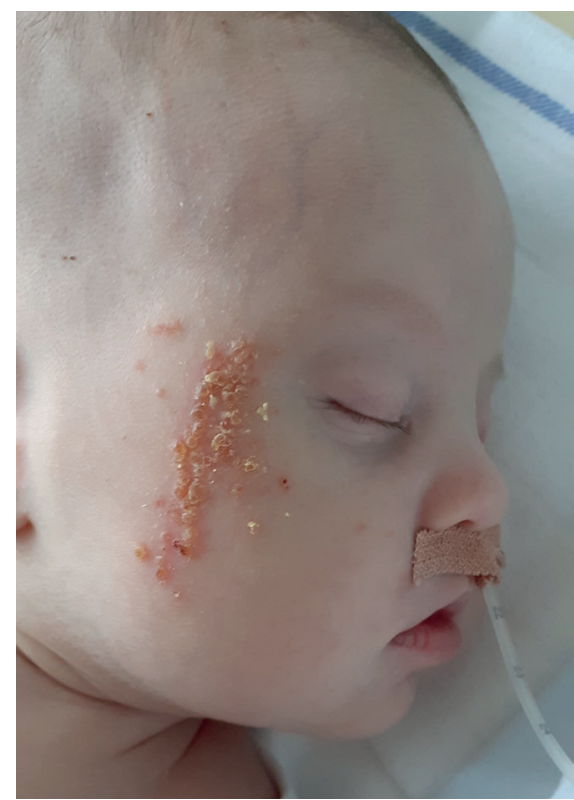

SLIKA 2. LEUKEMIA CUTIS - VEZIKULOPUSTULAREN IZPUŠČAJ PRI NOVOROJENČKU S PL-DS ZARADI INFILTRACIJE KOŽE Z BLASTI (NAŠ BOLNIK).

FIGURE 2. LEUKEMIA CUTIS - VESICULOPUSTULAR ERUPTION IN NEONATE WITH TL-DS DUE TO DIRECT INFILTRATION OF THE SKIN BY BLASTS (OUR PATIENT).

Pri simptomatskih bolnikih s PL-DS so zaradi infiltracije blastov prisotni naslednji klinični znaki, ki jih pri otrocih z DS brez mutacije gena GATA1 vidimo redko: hepatomegalija, splenomegalija, hepatopatija (povišane vrednosti transaminaz z direktno bilirubinemijo), perikardialni in plevralni izliv, kožni izpuščaj (papularen ali vezikulopustularen), hiperlevkocitoza s hiperviskoznnim sindromom in koagulopatija $(5,10,15,16)$. Infiltracija blastov v kostni mozeg ali trebušno slinavko je redkejša. PL-DS praviloma ne prizadene osrednjega živčnega sistema (15).

Ob prisotnosti enega ali več od naštetih kliničnih znakov pri novorojenčku z DS brez alternativnega vzroka moramo pomisliti na možnost PL-DS $(4,10)$.

Pljučna prizadetost se navadno pojavi pri bolj prizadetih bolnikih in je posledica mehanične kompresije pljuč zaradi masivne hepatomegalije ali plevralnega izliva (z blasti ali brez njih). Odpoved dihal je lahko tudi posledica pljučne kongestije zaradi hiperlevko-

Diagnostična merila za postavitev diagnoze PL-DS

1. trisomija 21: Downov sindrom ali mozaicizem;

2. dokazana mutacija gena GATA1 (ali izključna izraženost GATA1s v blastih);

3.a) prisotnost > $5 \%$ mieloidnih blastov v periferni krvi;

3.b) prisotnost s PL-DS povezanih znakov (organomegalija, hepatopatija (povišane vrednosti transaminaz z direktno hiperbilirubinemijo), značilen kožni izpuščaj, perikardialni in plevralni izliv, ekstremna levkocitoza in koagulopatija);

4. starost $\leq 3$ mesece.

TABELA 1. DIAGNOSTIČNA MERILA ZA POSTAVITEV DIAGNOZE PL-DS (POVZETO PO (4)).

TABLE 1. DIAGNOSTIC CRITERIA FOR DIAGNOSIS OF TL-DS (ADAPTED TO (4)).

citoze ali srčnega popuščanja s posledičnim hidropsom ploda. Ledvična odpoved ni posledica blastne infiltracije ali fibroze, ampak se pojavi sekundarno ob jetrnih ali srčnih zapletih ali kot posledica hiperviskoznosti zaradi hiperlevkocitoze (15).

Naš bolnik je imel s PL-DS povezano blago hepatosplenomegalijo in znake hiperviskoznega sindroma ob levkocitozi (motnje čuječnosti, motnje hranjenja in težave z dihanjem s hiperkapnijo), med bolnišničnim zdravljenjem pa se je na obrazu in v lasišču razvil tudi značilen vezikulopustularen izpuščaj (Slika 2). Dihanje skozi nos je oteževala verjetna levkemična infiltracija nosne sluznice.

Kožni infiltrati so vidni pri $5 \%$ bolnikov s PL-DS. Izpuščaj je sprva vezikulopustularen in postopno postane zlivajoč in krastav z eritematozno osnovo. Vidimo ga lahko že ob postavitvi diagnoze ali zgodaj v poteku bolezni. Pogosto se pojavi na obrazu, sicer pa lahko kjer koli drugje in lahko zajema različno velike površine. Biopsija pokaže peri- vaskularno ali kožno infiltracijo levkemičnih blastov in nezrele mieloidne celice, ki infiltrirajo epidermis. Spremembe sprva spominjajo na toksični eritem, a se sčasoma prično zlivati in nimajo eozinofilnega infiltrata, ki ga tipično vidimo pri toksičnem eritemu (17).

\section{Diagnosticiranje}

\section{Prisotnost blastov in mutacija gena GATA1}

V prospektivni raziskavi krvnih vzorcev novorojenčkov z Downovim sindromom so prisotnost blastov v periferni krvi potrdili pri kar $98 \%$ preučevancev (16).

Najbolj primeren čas za oceno deleža blastov je prvi teden življenja, idealno starost 3 dni. Kasneje se začne delež blastov hitro zmanjševati, kar je zavajajoče in lahko pri simptomatskih in življenjsko ogroženih otrocih privede do zakasnitve pri postavitvi diagnoze. Novorojenčki z DS, ki so majhni za nosečnostno starost, in novorojenčki z insuficienco posteljice prav tako zah- 
tevajo posebno pozornost, saj je delež blastov kljub prisotnosti mutacije gena GATA1 manjši (10).

$\checkmark$ priporočilih študijske skupine AML -BFM 2019 je diagnostično merilo PL-DS $>5 \%$ krožečih blastov v periferni krvi (4). V Smernicah za obravnavo PL-DS (BSH 2018 (10)) so kot diagnostično merilo določili > $10 \%$ blastov v periferni krvi na podlagi raziskave Robertsa, $v$ kateri je prag $>10 \%$ blastov v periferni krvi zajel vse simptomatske bolnike s PL-DS, pri katerih pa niso v vseh primerih dokazali mutacije gena GATA1. Pri pragu $>20 \%$ blastov so mutacijo gena GATA1 dokazali pri vseh bolnikih. Pri 20 $\%$ novorojenčkov z DS so potrdili t. i. tiho PL-DS, saj so imeli $<10 \%$ blastov in niso imeli bolezenskih znakov, a je bila mutacija gena GATA1 vseeno prisotna.

Pri $17 \%$ preučevancev s PL-DS in pri 5 $\%$ preučevancev s tihim PL-DS je kasneje prišlo do razvoja ML-DS. Noben novorojenček brez dokazane mutacije gena GATA1 ni imel znakov PL-DS in kasneje ni razvil ML-DS (16).

\section{Morfologija blastov, imunofenotipizacija in preiskava kostnega mozga}

Blasti prehodne motnje mielopoeze izvirajo iz spremenjenih megakariocitnih in/ali eritroidnih prekurzorjev v plodovih jetrih. Krožeči blasti so pleomorfni. Pogosto imajo prominentno jedro in bazofilno, vakuolizirano citoplazmo z izboklinami in megakariocitnimi fragmenti. Z imunofenotipizacijo jih razlikuujemo od blastov pri drugih levkemijah, saj izražajo kombinacijo označevalcev zarodnih celic (CD 34 in CD 117), mieloidnih označevalcev (CD33/CD13) in trombocitnih glikoproteinov (CD36, CD 41, CD 42b in CD61) ter povečano izraženost CD 56 in CD7 in nizko izraženost CD11a (11).

Preiskava kostnega mozga za postavitev diagnoze PL-DS in za napoved poteka bolezni ni nujno potrebna. Blastne celice izhajajo iz jeter, kostni mozeg pa ni nujno infiltriran. Prav tako resnost bolezni, verjetnost spontane remisije in verjetnost prehoda v ML-DS niso povezane s stopnjo prizadetosti kostnega mozga (5-7).

\section{Zdravljenje PL-DS}

Glavni vzrok zgodnje smrti pri otrocih s PL-DS je napredujoča hepatopatija s holestazo, ki vodi v fulminantno jetrno fibrozo, diseminirano intravaskularno koagulacijo in večorgansko odpoved. S PL-DS povezan zunajjetrni vzrok smrti je odpoved srca in dihal, ki je posledica malignega perikardialnega in plevralnega izliva, hidropsa ploda in ledvične odpovedi ali okužbe. Smrt lahko nastopi tudi nepovezano s PL-DS kot posledica kompleksne prirojene srčne napake ali drugih prirojenih anomalij $(5-7,10)$.

Dejavniki, povezani z zgodnjo umrljivostjo, so: veliko število levkocitov $\left(>100 \times 10^{9} / \mathrm{l}\right)$, ascites, prizadetost jeter (vključno s koagulopatijo), hidrops ploda in nedonošenost $(<37$. teden nosečnosti) ali nizka porodna teža (5).

$V$ dosedanjih raziskavah se je za zmanjšanje zgodnje umrljivosti otrok s PL-DS kot učinkovito izkazalo zdravljenje s citarabinom v nizkih odmerkih, ki zmanjša blastno breme in preprečuje zaplete, ki bi lahko vodili do zgodnje umrljivosti (4, 5, 18). Z zapoznelim zdravljenjem ne moremo popraviti hude jetrne okvare (5).

Znaki PL-DS, ki so povezani z zgodnjo umrljivostjo in pri katerih je priporočljivo zdravljenje s kemoterapijo po protokolu AML BFM 2019, so:

hiperlevkocitoza (> $100 \times 10^{9} / \mathrm{l}$ );

okvara jeter (hepatomegalija s povečano vrednostjo jetrnih testov in/ali holestazo);

- ascites;

hidrops ploda;

življenje ogrožajoči znaki, tj. znaki hiperviskoznosti, težave $z$ dihanjem zaradi organomegalije, srčno popuščanje (EF $<47 \%$ ali $S F<27 \%$ ), ki ni neposredno povezano s prirojeno srčno napako, ledvična okvara, DIK s krvavitvijo $(4,6)$.
Nekatere druge raziskovalne skupine vključujejo še plevralni izliv in perikardialni izliv $(6,10)$.

Pri otrocih brez naštetih kliničnih znakov zdravljenje ni indicirano. Zdravljenje s kemoterapijo namreč zmanjša tveganje zgodnje umrljivosti, medtem ko na tveganje za razvoj mieloblastne levkemije (ML-DS) ne vpliva (4).

Pri brezsimptomnih bolnikih $v$ času prehoda hematopoeze iz plodovih jeter $v$ kostni mozeg pride do spontane remisije (19). V primeru spontane remisije pri simptomatskih bolnikih najprej izginejo blasti, medtem ko se hepatomegalija razreši kasneje (6).

V Sloveniji smo pridruženi raziskovalni skupini AML BFM, ki po aktualnem protokolu svetuje zdravljenje s citarabinom v odmerku $1,5 \mathrm{mg} / \mathrm{kg}$ TT (počasi, $v$ več kot 5 minutah) intravensko ali v obliki podkožnih injekcij enkrat dnevno 5-7 dni. Če ni zadostnega odgovora, se po 2-do 7-dnevnem premoru odločimo za dodaten cikel (4).

\section{Kontraindikacije za pričetek zdravljenja:}

mieloidna levkemija ali mielodisplastični sindrom;

anemija $(\mathrm{Hb}<90 \mathrm{~g} / \mathrm{l})$, trombocitopenija $\left(\mathrm{T}<100 \times 10^{9} / \mathrm{l}\right)$ in/ali nevtropenija $\left(<0,5 \times 10^{9} / l\right)$, ki niso povzročene s PL-DS (npr. ITP, prirojena nevtropenija ali hemolitična anemija);

predhodna presaditev organov;

dokaz invazivne glivične okužbe ali hude sistemske okužbe, ki zahteva sistemsko/parenteralno zdravljenje (vključno z aktivno virusno okužbo s HIV ali hepatitisom B in hepatitisom C); simptomatska bolezen srca (CTCAE 5.0 stopnje 3 ali stopnje 4);

- večji kirurški poseg, načrtovan v 21 dneh od predvidenega prvega odmerka citarabina (4).

$V$ našem primeru smo se za kemoterapevtsko zdravljenje odločili zaradi vztrajanja levkocitoze, ki je povzročala hiperviskozni sindrom in težave z dihanjem. Ob zdravljenju je prišlo do klinič- 
1. hemogram z DKS za oceno deleža blastov v periferni krvi (optimalno opraviti v Specializiranem hematološkem laboratoriju Pediatrične klinike v Ljubljani v prvem tednu)

2. genetski/citogenetski test za potrditev trisomije 21

3. pregled za oceno kliničnih značilnosti PL-DS:

organomegalija

hidrops ploda

plevralni/perikardialni izliv

kožni izpuščaj

\section{$>5 \%$ blastov ali klinične značilnosti PL-DS?}

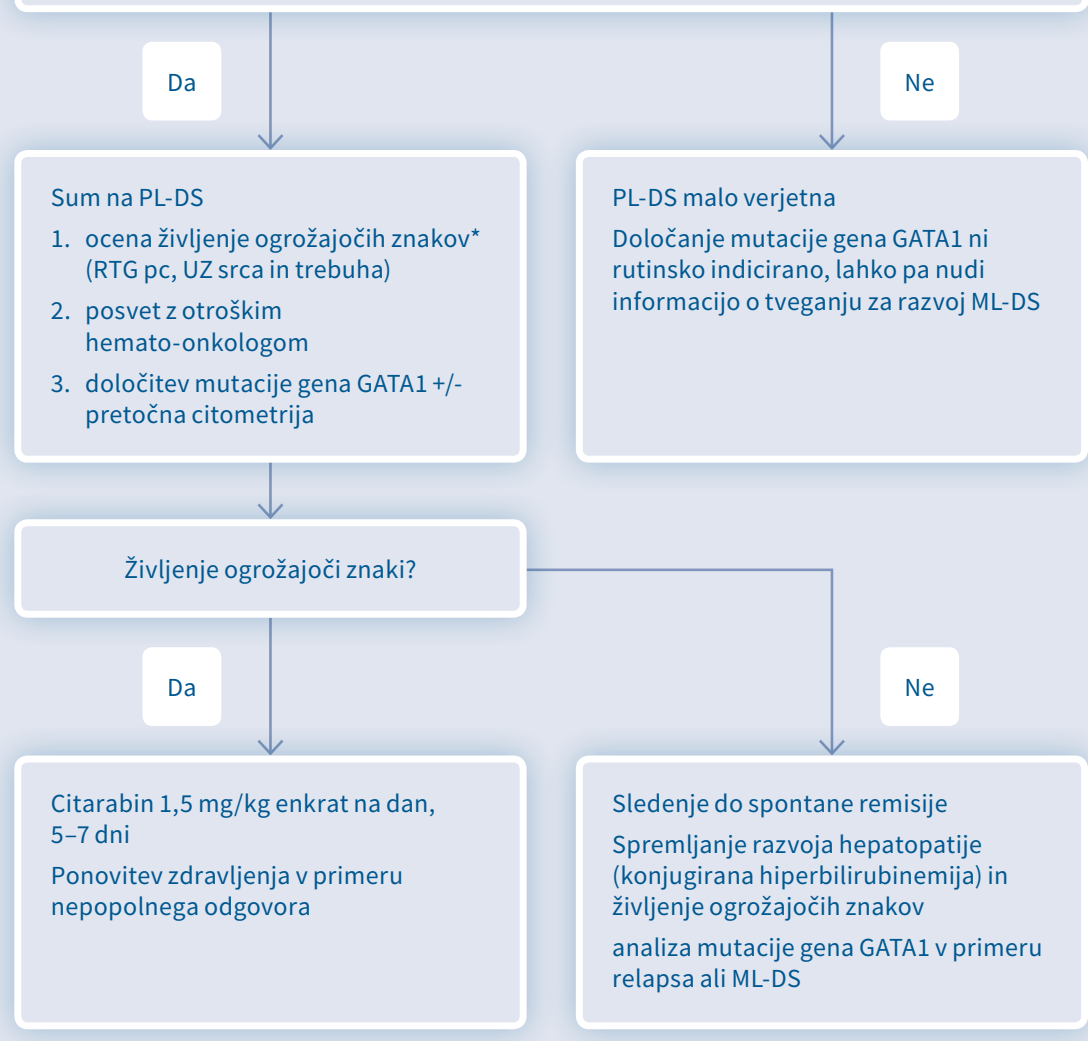

*Življenje ogrožajoči znaki:

1. večorganska odpoved

2. levkocitoza $>100 \times 109 / 1$

3. hepatopatija (konjugirani bilirubin $>83$ mikromol/l)

4. hepatosplenomegalija (pod popkom ali povzroča dihalno stisko ali otežuje hranjenje)

5. hidrops ploda

6. plevralni ali perikardialni izliv

7. ledvična odpoved

8. DIK s krvavitvijo

SLIKA 3. SMERNICE ZA PREISKAVO IN OBRAVNAVO PREHODNE LEVKEMIJE DOWNOVEGA SINDROMA (4, 10) (PRIREJENO PO SMERNICAH ŠTUDIJSKIH SKUPIN AML BFM 2019 IN BSH 2018 (ANGL. THE BRITISH SOCIETY FOR HAEMATOLOGY)).

FIGURE 3. GUIDELINES FOR INVESTIGATION AND MANAGEMENT OF TRANSIENT LEUKAEMIA OF DOWN SYNDROME $(4,10)$ (ADAPTED FROM GUIDELINES OF AML BFM 2019 AND BSH 2018 (THE BRITISH SOCIETY OF HAEMATOLOGY)) nega izboljšanja (izzvenele so težave z dihanjem, koža se je zacelila) in znižanja števila levkocitov. Deček je bil do prehoda v ML-DS pri 11 mesecih klinično brez večjih težav in v remisiji.

\section{Zgodnje odkrivanje ML-DS}

V blastih bolnikov, ki so po PL-DS razvili tudi ML-DS, so dokazali prisotnost za bolnika specifične mutacije gena GATA1, ki je bila prisotna že v času predhodne PL-DS. Po hipotezi naj bi v primeru eradikacije blastov z mutacijo gena GATA1 že v obdobju PL-DS preprečili prehod v ML-DS. Izsledki najnovejšh raziskav kažejo, da s kemoterapijo s citarabinom v obdobju PL-DS ne preprečimo in ne zmanjšamo verjetnosti prehoda do ML-DS. Z leti se pojavijo dodatne somatske mutacije, ki predlevkemične klone PL-DS pretvorijo $v$ ML-DS (4).

ML-DS se razvije le pri otrocih s trisomijo 21, ki imajo že ob rojstvu prisotno mutacijo gena GATA1, kar nakazuje, da bi aktivno iskanje bolnikov, ki imajo mutacijo gena GATA1 (tudi tistih s »tihim PL-DS«), pomagalo pri zaznavanju otrok $z$ večjim tveganjem za razvoj ML-DS (20).

Pri vseh oblikah PL-DS zaradi povečanega tveganja za razvoj ML-DS priporočamo redno spremljanje $s$ kontrolnim spremljanjem kliničnega statusa, hemograma, diferencialne krvne slike in krvnega razmaza ter glede na potek ugotavljanje prisotnosti celic $z$ aberantnim imunofenotipom, sprva v periferni krvi, nato pa po potrebi tudi v kostnem mozgu $(4,9)$. Zaznana MRD v 12. tednu po postavitvi diagnoze PL-DS je povezana z večjim tveganjem razvoj ML-DS (21). Klinično se ML-DS ne odraža s posebnimi zna$\mathrm{ki}$, razen s posrednimi znaki anemije, trombocitopenije ali nevtropenije (4). Otroci z ML-DS imajo boljšo napoved izida bolezni kot otroci z AML brez DS, saj so njihove blastne celice bolj občutljive na kemoterapijo, zlasti na citarabin in antraciklinske antibiotike.

Preživetje otrok z ML-DS je ob ustreznem zdravljenju 87-93 \% brez pot- 
rebe po presaditvi kostnega mozga. Smrtnost je povezana predvsem $z$ zapleti kemoterapije, zato potekajo številne raziskave, usmerjene $v$ iskanje optimalnega zdravljenja z nizkimi odmerki, ki bi omogočilo čim manjšo toksičnost zdravljenja in vseeno preprečevalo relaps bolezni. Napoved izida bolezni je pri bolnikih z ML-DS po ponovitvi bolezni slaba (4).

\section{Zaključek}

Pravočasno odkrivanje prehodne levkemije oz. prehodne motnje mielopoeze pri novorojenčkih z Downovim sindromom (PL-DS) je ključno za uspešno zdravljenje in preprečevanje zgodnje smrti, povezane s fibrozo jeter in končno jetrno odpovedjo.

Usmerjeno iskanje mutacije gena GATA1 je poleg vloge pri potrditvi diagnoze PL-DS pomembno tudi za prepoznavanje tistih bolnikov, ki zdravljenja v zgodnjem obdobju sicer ne potrebujejo, imajo pa večje tveganje za razvoj mieloidne levkemije, povezane z Downovim sindromom (ML-DS). Te otroke moramo redno spremljati pri hemato-onkologu, saj z zgodnjim odkrivanjem in zdravljenjem ML-DS preprečimo življenje ogrožajoče zaplete pri napredovali bolezni.

V prispevku objavljamo priporočila za obravnavo prehodne levkemije Downovega sindroma (Slika 3) v Sloveniji. Pri vsakemu novorojenčku s sumom na Downov sindrom moramo v prvem tednu življenja v specializiranem hematološkem laboratoriju preveriti hemogram in diferencialno krvno sliko. $\mathrm{V}$ primeru povečanega deleža blastov (> $5 \%$ ) v periferni krvi ali prisotnosti simptomov, sumljivih za PL-DS, se posvetujemo s pediatričnim hemato-onkologom glede nadaljnje diagnostične obravnave (odvzem vzorca krvi za analizo prisotnosti mutacije gena GATA1) ter glede potrebe po zdravljenju in nadaljnjem sledenju.
Literatura

1. Žerjav Tanšek M, Battelino T. Humana genetika Pediatrija. Prva izdaja. Ljubljana: DZS; 2014: 172

2. Henry E, Walker D, Wiedmeier SE, Christensen RD. Hematological abnormalities during the first week of life among neonates with Down syndrome: data from a multihospital healthcare system. Am J Med Genet A 2007; 143A(1): 42-50.

3. Hasle H. Pattern of malignant disorders in individuals with Down's syndrome. Lancet Oncol 2001; 2: 429-36

4. Klussman JH. Myeloproliferative disorders in patients with Down syndrome, Treatment reccomendations. AML-BFM 2019; 51-70.

5. Klusmann JH, Creutzig U, Zimmermann M, Dworzak M, Jorch N, Langebrake C et al. Treatment and prognostic impact of transient leukemia in neonates with Down syndrome. Blood 2008; 111(6): 2991-8.

6. Gamis AS, Alonzo TA, Gerbing RB, Hilden JM, Sorrell AD, Sharma M et al. Natural history of transient myeloproliferative disorder clinically diagnosed in Down syndrome neonates: a report from the Children's Oncology Group Study A2971. Blood 2011; 118: 6752-9.

7. Massey GV, Zipursky A, Chang MN, Doyle JJ, Nasim S, Taub JW et al. Children's Oncology Group (COG). A prospective study of the natural history of transient leukemia (TL) in neonates with Down syndrome (DS): Children's Oncology Group (COG) study POG-9481. Blood 2006; 107(12): 4606-13.

8. Creutzig U, Reinhardt D, Diekamp S, Dworzak M, Stary J, Zimmermann M. AML patients with Down syndrome have a high cure rate with AML-BFM therapy with reduced dose intensity. Leukemia 2005; 19(8): 1355-60.

9. Garnett C, Cruz Hernandez D, Vyas P. GATA1 and cooperating mutations in myeloid leukaemia of Down syndrome. IUBMB Life 2020; 72(1): 119-30.

10. Tunstall O, Bhatnagar N, James B, Norton A, O'Marcaigh AS, Watts T et al. British Society for Haematology. Guidelines for the investigation and management of Transient Leukaemia of Down Syndrome. Br J Haematol 2018; 182(2): 200-11.

11. Langebrake C, Creutzig U, Reinhardt D. Immunophenotype of Down syndrome acute myeloid leukemia and transient myeloproliferative disease differs significantly from other diseases with morphologically identical or similar blasts. Klin Padiatr 2005; 217: 126-34.

12. Chou ST, Opalinska JB, Yao Y, Fernandes MA, Kalota A, Brooks JS et al. Trisomy 21 enhances human fetal erythro-megakaryocytic development. Blood 2008; 112(12): 4503-6.

13. Tunstall-Pedoe O, Roy A, Karadimitris A, de la Fuente J, Fisk NM, Bennett P et al. Abnormalities in the myeloid progenitor compartment in Down syndrome fetal liver precede acquisition of GATA1 mutations. Blood 2008; 112(12): 4507-11.

14. Tamblyn JA, Norton A, Spurgeon L, Donovan V, Bedford Russell A, Bonnici J et al. Prenatal therapy in transient abnormal myelopoiesis: a systematic review. Arch Dis Child Fetal Neonatal Ed 2016; 101(1): F67-71.

15. Gamis AS, Smith FO. Transient myeloproliferative disorder in children with Down syndrome: clarity to this enigmatic disorder. Br J Haematol 2012; 159(3): 277-87.
16. Nijhawan A, Baselga E, Gonzalez-Ensenat MA, Vicente A, Southern JF, Camitta BM et al. Vesiculopustular eruptions in Down syndrome neonates with myeloproliferative disorders. Arch Dermatol 2001; 137(6): 760-3.

17. Roberts I, Alford K, Hall G, Juban G, Richmond $\mathrm{H}$, Norton A et al. GATA1-mutant clones are frequent and often unsuspected in babies with Down syndrome: identification of a population at risk of leukemia. Blood 2013;122: 3908-17.

18. Al-Kasim F, Doyle JJ, Massey GV, Weinstein HJ, Zipursky A. Incidence and treatment of potentially lethal diseases in transient leukemia of Down syndrome: Pediatric Oncology Group Study. J Pediatr Hematol Oncol 2002; 24: 9-13.

19. Roy A, Roberts I, Norton A, Vyas P. Acute megakaryoblastic leukaemia (AMKL) and transient myeloproliferative disorder (TMD) in Down syndrome: a multi-step model of myeloid leukaemogenesis. $\mathrm{Br} \mathrm{J}$ Haematol 2009; 147(1): 3-11.

20. Pine SR, Guo Q, Yin C, Jayabose S, Druschel CM, Sandoval C. Incidence and clinical implications of GATA1 mutations in newborns with Down syndrome. Blood 2007; 110(6): 2128-31.

21. Flasinski M, Scheibke K, Zimmermann M, Creutzig U, Reinhardt K, Verwer F et al. Low-dose cytarabine to prevent myeloid leukemia in children with Down syndrome: TMD Prevention 2007 study. Blood Adv 2018; 2: 1532-40.

Vita Čas, dr. med.

Zdravstveni dom Laško, Otroški

dispanzer, Laško, Slovenija

doc. dr. Aneta Soltirovska Šalamon, dr. med.

Kinični oddelek za neonatologijo, Pediatrična klinika, Univerzitetni klinični center Ljubljana, Ljubljana, Slovenija

doc. dr. Marko Kavčič, dr. med. (kontaktna oseba / contact person)

Klinični oddelek za otroško

hematologijo in onkologijo,

Pediatrična klinika, Univerzitetni klinični center Ljubljana, Bohoričeva ulica 20, 1000 Ljubljana, Slovenija e-naslov: marko.kavcic@kclj.si

prispelo / received: 10.6. 2021

sprejeto / accepted: 21. 9. 2021

Čas V, Soltirovska Šalamon A, Kavčič M. Prehodna levkemija (prehodna motnja mielopoeze) pri novorojenčku z downovim sindromom. Slov Pediatr 2021; 28(4): 200-206. https://doi.org/10.38031/ slovpediatr-2021-4-03. 